\title{
Students' Perception on Online Application in Speaking Skill
}

\begin{abstract}
Rifari Baron
Posgraduate Program Universitas Indraprasta PGRI Jakarta, Indonesia

Correspondence: Rifari Baron, Posgraduate Program Universitas Indraprasta PGRI Jakarta, Indonesia. email: rifari.baron@unindra.ac.id

Submitted: September 03, 2020

Revised: October 16, 2020

Accepted: October 17, 2020

DOI: $10.29408 /$ veles.v4i2.2543

URL: http://dx.doi.org/10.29408/veles. v4i2.2543

Abstract

Online applications become a medium that helps the learning process of English in the classroom easier. Many online applications can be used to learn to speak English. Therefore, the aim of this study is to identify suitable online applications for learning to speak English that suits student needs. The research method uses descriptive qualitative. The data collection process is interview, observation, and questionnaire. Data analysis used three steps, namely data reduction, data display, and conclusion drawing. The results showed that the zoom and google hangouts meet is a popular video application. While website Youtube is a web application chosen interestingly for English speaking learning and social media WhatsApp is easy to use in English speaking learning. It is able to make a group. The implication of study is to increase teacher's creativity to use the online application.
\end{abstract}

Keywords: English, online application, speaking skills

\section{Introduction}

During the Covid-19 pandemic, the teaching and learning process must be carried out online or e-learning. This of course requires educators to be able to create or take advantage of various online applications for the learning process so that the learning objectives to be achieved can be achieved precisely. Currently, many applications can be accessed free of charge to support the good learning process which is intended for learning such as zoom, google meet, and so on. websites designed for online learning such as teacher rooms, Quipper, or websites from universities specifically designed for online learning such as Moodle. while social media that are often used for learning purposes include telegram, WhatsApp, Instagram, Facebook, and so on.

Some research has been conducted using online applications on a wide range of English language skills. The Internet is considered a powerful, accurate and precise resource bank and tool that can be used in foreign language education (Arikan, 2014), like as reading online text (Park \& Kim, 2017). The students believe that FB can be used as an online environment to facilitate learning English (Kabilan, Ahmad, \& Abidin, 2010). While, online games are proven to be more 
effective in learning English vocabulary for students (Ashraf, Motlagh, \& Salami, 2014). It means that online strategy games can be valuable instructional tools that can be used in the context of communicative language teaching (Erkir, 2015). Another research is about development and effectiveness of learning Arabic in the future through online games in schools (Hamizul \& Rahimi, 2015). Thus, the role of online learning technologies is be a new element framework for students in improvement of learning situation (Ellis \& Bliuc, 2019a). The accessibility of online resources in English means that today's informal context offers many opportunities for language development. In terms of perceived communicative competence and online informal English learning, the results indicate the co-evolution of two complex dynamic systems: the use of digital contexts in English and the participant's level of communicative competence level systems in English (Jurkovič, 2019).

From these previous studies, it can be concluded that many English learning processes have been successful in improving English language skills, such as grammar, vocabulary mastery, writing, and reading. However, from these studies, the implementation of online applications in English speaking learning has not been clearly described. Therefore, this study refers to the identification of various kinds of online applications in English speaking learning as students' perceptions. Moreover, English speaking learning requires a lot of practice in interacting with other people.

Speaking skills are a communication ability that a person possesses in expressing ideas, and thoughts to convey to the interlocutor. The communication process aims to convey an idea to the other person to get a response of the information submits. Speaking Learning is to train students to speak in good and true language, even a complex ability that involves factors, namely in the readiness to learn, readiness of thinking, motivation and guidance. Speaking activity has its own advantages in the classroom. It conveys a message or meaning in the form of an idea to transactional in oral. Moreover, speaking a sentence that students must do in a conversation, especially in a pronunciation of vocabulary and grammar that it is owns by students as well should also be further improves.

Many studies show the difficulty of mastering English speaking skills. In fact, speaking English is not easy. Speaking is an interactive process of constructing meaning that involves the production, reception and processing of information. Some of the factors that cause problems in speaking to students, first are poor reading habits, unequal participation and practice of English both inside and outside the classroom, and confusion in the application of grammar rules (Sayuri, 2016). Student interaction plays an important role in the classroom because students are able to improve their speaking skills in a classroom setting. This analysis also confirms the important concern for the use of student interaction instruction in the development of speaking skills (Saeed, Khaksari, Eng, \& Ghani, 2016).

Mastery of short sentences can help students to speak (Kitagaki, 2013). Besides, speaking English should be done in a fun way like a game. Students enjoy learning and gain more motivation, interest and confidence through their learning. Therefore, communicative games must be applied as activities designed to teach speaking skills. It is recommended that such studies 
should be retained and extended to other language skills (Dewi, Kultsum, \& Armadi, 2016). Learning that involves audio visual elements provides benefits for mastery of English speaking skills. Moreover, currently the mobile facility has been equipped with various applications that can be used to learn English speaking. Moreno \& Vermeulen (2015) shows that developing a mobileassisted language learning application called VISP (VIdeos for Speaking), which uses audio description techniques to improve accuracy and fluency in spoken production. Another study concluded that English teachers have a positive perception of using YouTube to develop speaking skills. YouTube videos help students guess the meaning of foreign words and improve speaking skills (Albahlal \& Albahlal, 2019).

This research needs to be done for several reasons that 1 ) the need for online applications is different between students, 2) the background of students in mastery of online applications, 3) the ability to provide internet quota for students so that assumptions are needed for students towards effective and efficient online applications, and 4 ) learning to speak requires students to have direct contact with their friends so that learning activities must be face to face. Therefore, online applications are one of the best solutions in meeting the needs of learning to speak English in the Covid-19 pandemic situation. Thus, this research provides a novelty that has not been previously discussed. The purpose of the study was to get a good online application as students' needs in English speaking skills learning.

\section{Method}

The study used descriptive qualitative method. Qualitative research focused on understanding social phenomena from the perspective of the human participants in natural settings. So, descriptive qualitative method means to describe the result of observation with the help data search from existing sources (Ary, Jacobs, Sorensen, \& Razavieh, 2010).

\subsection{Participants}

This study had the participant that was taken from the postgraduate students in English Language Program Universitas Indraprasta Jakarta. It was taken from 2019/2020 academic years that was conducted in January until August 2020. Participants in this study were postgraduate students who received the Speaking course. There are 20 participants. The technique of determining participants as sample research used purposive sampling. This technique is used to select informants which was done deliberately according to the ability of students in terms of themes, concepts and phenomena studied in the study (Robinson, 2014).

\subsection{Process of Collecting Data}

The process of collecting data used observation, interview, and questionnaire. The observation is taken from the process of speaking skills e-learning which observed the students' behavior on online application. Interview is taken after the speaking skills e-learning after the learning process has done. While questionnaire used to collect students' perception toward online application in speaking skill learning. 


\subsection{Data Analysis}

Data analysis used the stages of data reduction, data display, and drawing conclusions (Miles \& Huberman, 1994). Data reduction refers to the process of selecting, focusing, simplifying, abstracting, and transforming the data in written up field note or transcript. Generally, a display is an organized, compressed assembly of information that permits conclusion drawing and action. In this step the researcher concludes the result of the research based on the research problems

\section{Results}

The distribution of questionnaires is given to students consists of three components, namely information about video call applications, website applications, and social media. The questions are given to students in the form of a questionnaire aim to determine students' perceptions of the use of video calls, websites, and social media. The following is a graph of the percentage obtained for each component in question to the students.

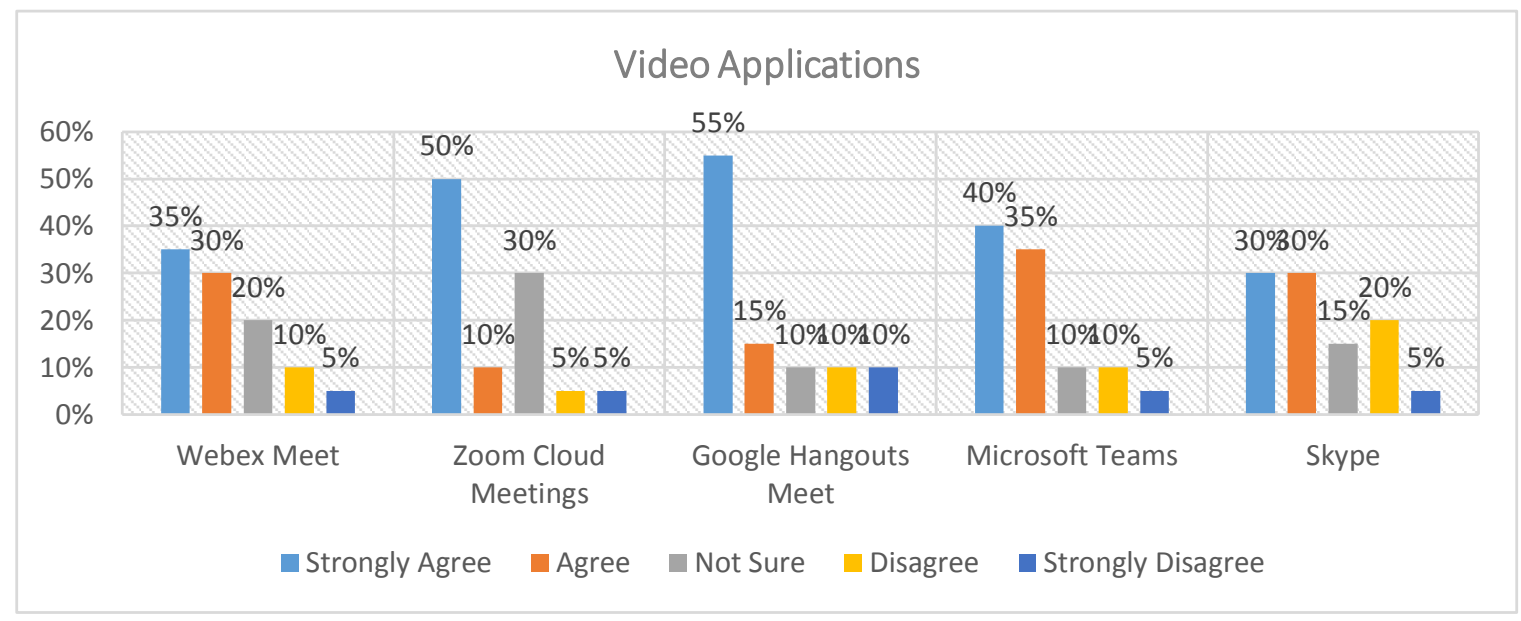

Graph 1. Video Online Application in English Speaking Learning

Graph 1 concludes that students have google hangouts meet and zoom cloud meetings to carry out learning in the form of video calls instead of face-to-face learning to practice speaking English. This can be seen from the results of the largest percentage, namely google hangouts meet by $55 \%$ and zoom cloud meetings by $50 \%$. This data was confirmed by the results of interviews with students who stated that Google Hangouts Meet and Zoom Cloud Meetings were easy to use and the quota requirement was not large either. In addition, these two online applications also have an attractive appearance and are easy to use. While the percentage of implementing website applications can be seen in the following graph. 


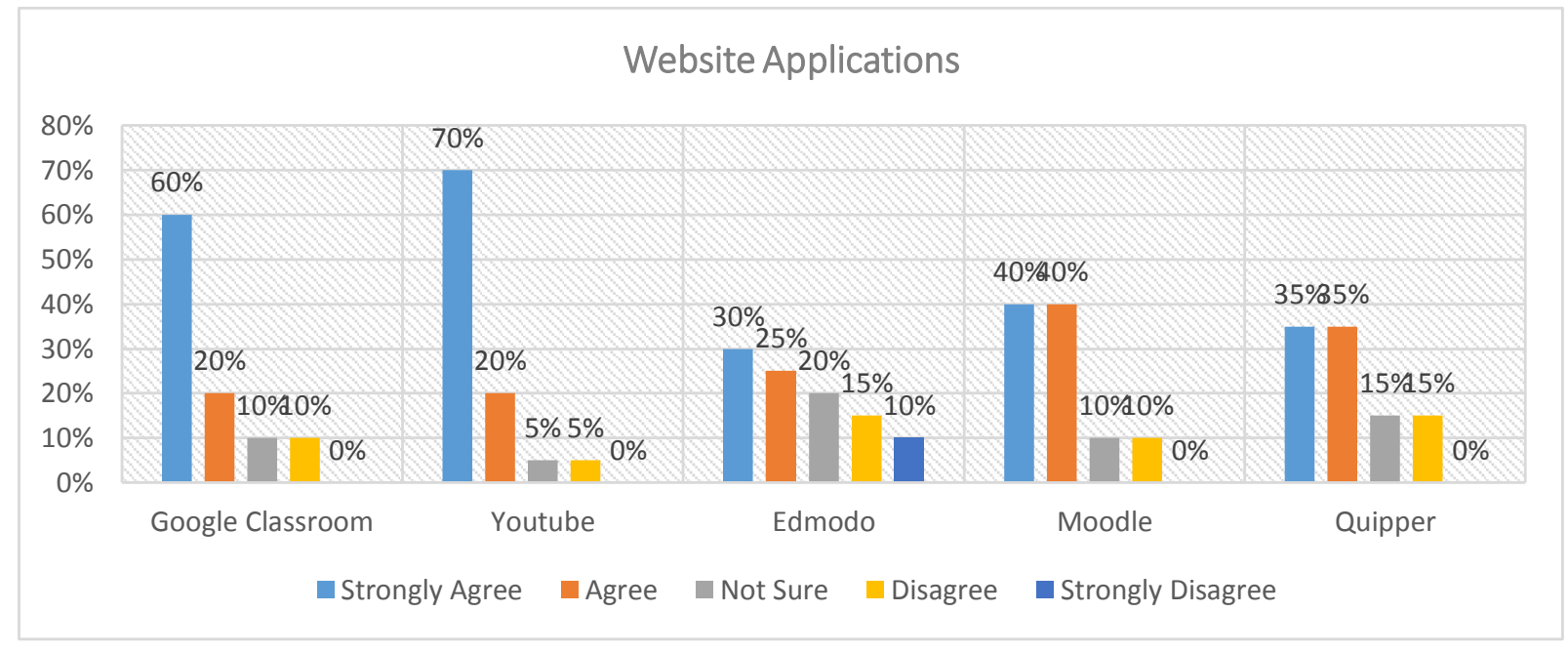

Graph 2. Website Online Application in English Speaking Learning

Graph 2 illustrates that students have Youtube by $70 \%$ as the right medium to learn English speaking. From the results of the interviews, students argued that they could easily make monologue videos and upload them to Youtube so that the teacher could easily provide an assessment. Likewise, peers can comment on deficiencies or mispronunciation. Apart from YouTube, students also choose google classroom by $60 \%$ as the second online website suitable for learning to speak English. According to students, google classroom has a fairly complete menu. This is because the teacher can give assignments and correct assignments easily. Students or teachers can use word, ppt, or video files. Apart from video applications and website applications, the learning process of English speaking also utilizes social media as a form of communication. The following is the result of the percentage of social media use.

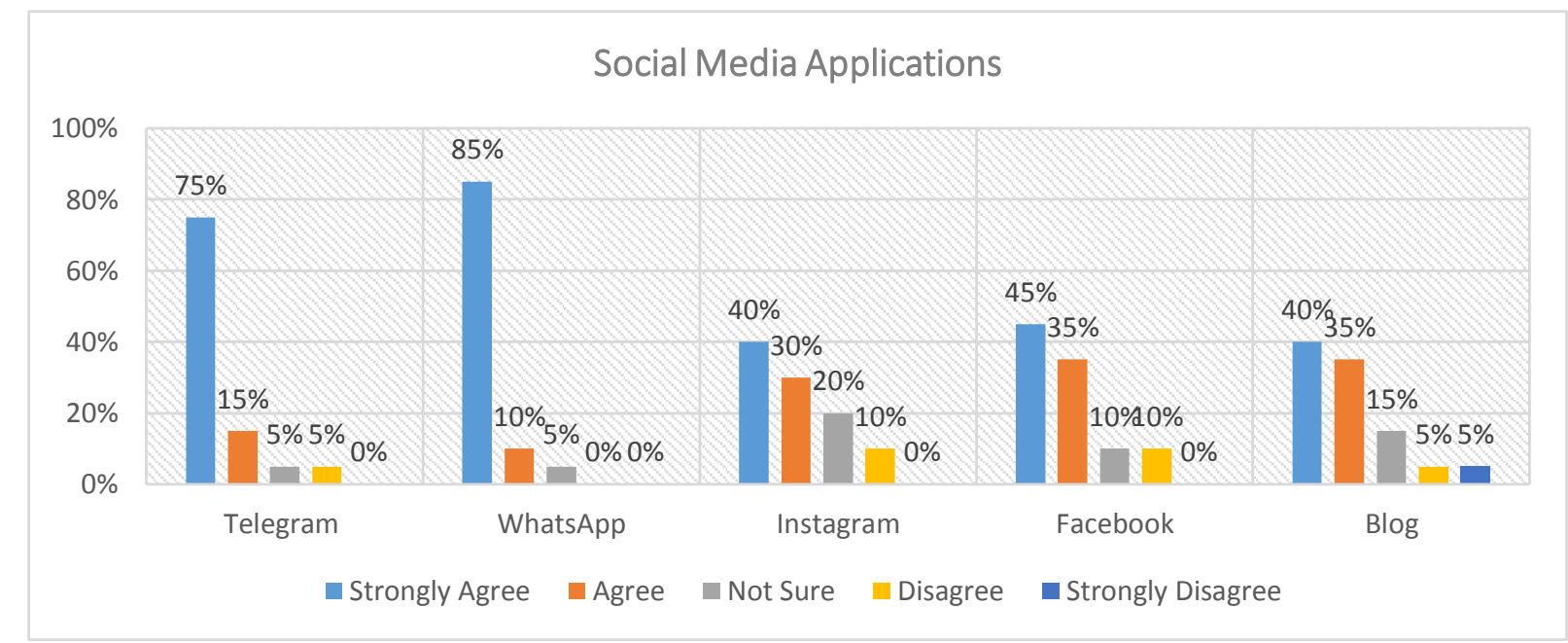

Graph 3. Social Media Online Application in English Speaking Learning

Graph 3 shows that the learning process to speak English for postgraduate students at Indraprasta University Jakarta is also carried out by utilizing social media. From the choices given to students, it is known that WhatsApp is the social media that many students like in 
communicating. This can be seen from the percentage obtained by $85 \%$. WhatsApp is considered popular to be used by people and almost all students use the WhatsApp application to communicate. Moreover, in this application, students can receive or send files in the form of work, ppt, or video.

\section{Discussion}

From the results of data distribution, it is known that English speaking learning is done online is mostly done using zoom cloud meetings and google hangouts. Both online media are used when students practice speaking using dialogue. Meanwhile, the speaking practice is carried out in monologue using YouTube. Students make video monologues about a theme and the video is uploaded on Youtube because the use of YouTube media is quite popular among students. YouTube is considered an effective tool that can enhance the learning experience if the video is truly relevant to the subject being discussed. It is recommended that instructors integrate YouTube into their respective learning to take advantage in the learning / teaching context (Moghavvemi, Sulaiman, Jaafar, \& Kasem, 2018). It can be concluded that YouTube is be as tools to improve students' English speaking skills.(Riswandi, 2016). It is relevance in English speaking skills during online learning process (Albahlal \& Albahlal, 2019).

In addition, to facilitate of the learning communication used WhatsApp so that the difficulties are faced by students in the learning process can be done easily and quickly. The advantage of online media learning webinars such as Skype and Zoom is their ability to allow participants to interact in writing and orally and share presentation screens through the display sharing feature. Since one of the most important factors in online learning is the internet, Zoom is recommended over Skype.(Cuaca Dharma, Asmarani, \& Dewi, 2017). The results of this research are new and important knowledge for teachers to make improvements during the Covid-19 pandemic. This means that the learning process carried out online can still be carried out optimally like offline learning.

There are several reasons that the results of this study are important and useful for learning to speak English, i.e 1) the process of English speaking learning is carried out through a combination of online applications, namely video, website applications or social media. 2) The combination of learning applications has made it easy for teachers to direct and guide students to improve their English speaking skills. 3) Teachers can give the feedback on students' speaking learning as directly. 4) Teacher and students can make a good interaction during learning process. 5) The research provides findings of learning media that are appropriate for the online learning process during a pandemic. Thus, online media learning is effective for English speaking learning. As online learning technology becomes an integral part of the learning experience at universities, the quality of student learning is increasingly shaped by their experiences using online learning media (Ellis \& Bliuc, 2019b)

During the speaking learning process, students practice speaking using Zoom Cloud Meetings and they can also share material concepts discussed in the conversation. In addition, for some discussion groups, students were more comfortable using Google Hangouts Meetings. Both 
of these applications are used during the learning process to speak English for one semester. For teachers, learning materials use videos uploaded to Youtube. The use of online videos to learn speaking skills has introduced visual perception to students in developing speaking competence (Lee \& Liang, 2012). In google classroom, it is mostly used to transfer assignments and correct assignments. As it is known that many online learning programs have been implemented in various countries. In Romania has developed a burning project using the CALL (Computer Assisted Language Learning) method and the eTandem Method (Dina \& Ciornei, 2013).

In this study, several limitations were found from using Zoom Cloud Meetings, namely the limited access time due to students using the free zoom access. Meanwhile, Google Hangouts Meetings has a longer access time when compared to Zoom. Therefore, students have more Google Hangouts Meeting compared to Zoom. While the advantages of using Google Classroom are that students and teachers can provide comments or communicate on corrected assignments. Students also find it difficult to reduce the size of the video that they want to upload to YouTube. They need a long process to upload videos even though students feel that uploading on YouTube is more practical. Especially at this time, many students also like using YouTube to share various information.

The results of this study have implications for the understanding of teachers in managing online application learning for learning English skills such as speaking. This understanding is aimed at the ability of teachers in teaching management, because teachers must know the needs of instructional media or teaching strategies that are appropriate to student needs. From this study, it provides an illustration that for the learning process to speak English during the Covid-19 pandemic, students have more to use Zoom Cloud Meetings and Google Hangouts Meetings. While websites that are easy to use in the assignment distribution process are Google Classroom.

\section{Conclusion}

This study concludes that students have used Zoom Cloud Meetings and Google Hangouts Meetings to practice in person with their friends. This is due to the ease of using the online application. They can use the online zoom application and google hangouts meeting via smartphone or laptop. However, for speaking learning activities carried out in a monologue, students have to use YouTube so that the teacher can make corrections whenever their assignments are. In addition, students also have to use Google Classroom in uploading practice assignments in the form of words or power points. For further research, the results suggest that researchers should prepare a longer research time in observing the use of online learning media so that the level of effectiveness on learning outcomes is maximum. In addition, research that can be continued to implement the online learning media in integrated English learning skills.

\section{Acknowledgements}

The researcher would like to thank the students who have been involved and helped the research process and all parties who have become sources of reference. 


\section{References}

Albahlal, F., \& Albahlal, F. S. (2019). The impact of youtube on improving secondary school students' speaking skills: english language teachers' perspectives. Journal of Applied Linguistics and Language Research, 6(2), 1-17. Retrieved from http://www.jallr.com/ jallrir/index.php/JALLR/article/view/971

Arikan, A. (2014). An Examination of online grammar teaching materials available for young learners. Procedia - Social and Behavioral Sciences, 158, 18-22. https://doi.org/10.1016/J.SBSPRO.2014.12.026

Ary, D., Jacobs, L. C., Sorensen, C., \& Razavieh, A. (2010). Introduction to research in education (8 Edition). CA: Cengage Learning.

Ashraf, H., Motlagh, F. G., \& Salami, M. (2014). The impact of online games on learning english vocabulary by iranian (low-intermediate) efl learners. Procedia - Social and Behavioral Sciences, 98, 286-291. https://doi.org/10.1016/J.SBSPRO.2014.03.418

Cuaca Dharma, H. R., Asmarani, D., \& Dewi, U. P. (2017). Basic japanese grammar and conversation e-learning through skype and zoom online application. Procedia Computer Science, 116, 267-273. https://doi.org/10.1016/J.PROCS.2017.10.055

Dewi, R. S., Kultsum, U., \& Armadi, A. (2016). Using communicative games in improving students' speaking skills. English Language Teaching, 10(1), 63. https://doi.org/10.5539/elt.v10n1p63

Dina, A. - T., \& Ciornei, S. (2013). Online learning programmes for less widely used and taught languages. Procedia - Social and Behavioral Sciences, 70, 1820-1824. https://doi.org/10.1016/J.SBSPRO.2013.01.258

Ellis, R. A., \& Bliuc, A.-M. (2019a). Exploring new elements of the student approaches to learning framework: The role of online learning technologies in student learning. Active Learning in Higher Education, 20(1), 11-24. https://doi.org/10.1177/1469787417721384

Ellis, R. A., \& Bliuc, A.-M. (2019b). Exploring new elements of the student approaches to learning framework: The role of online learning technologies in student learning. Active Learning in Higher Education, 20(1), 11-24. https://doi.org/10.1177/1469787417721384

Erkir, S. (2015). An online strategy game for the classroom. Procedia - Social and Behavioral Sciences, 199, 50-56. https://doi.org/10.1016/J.SBSPRO.2015.07.486

Hamizul, M., \& Rahimi, N. M. (2015). Design and development of arabic online games - a conceptual paper. Procedia - Social and Behavioral Sciences, 174, 1428-1433. https://doi.org/10.1016/J.SBSPRO.2015.01.771

Jurkovič, V. (2019). Online informal learning of English through smartphones in Slovenia. System, 80, 27-37. https://doi.org/10.1016/J.SYSTEM.2018.10.007

Kabilan, M. K., Ahmad, N., \& Abidin, M. J. Z. (2010). Facebook: An online environment for learning of English in institutions of higher education? The Internet and Higher Education, 13(4), 179-187. https://doi.org/10.1016/J.IHEDUC.2010.07.003

Kitagaki, I. (2013). Effect of english short sentences memorization on the speaking skill and the e-learning of english. Procedia - Social and Behavioral Sciences, 103, 348-351. 
https://doi.org/10.1016/J.SBSPRO.2013.10.343

Lee, Y. J., \& Liang, J.-C. (2012). Using video technology to diagnose efl students' cognitive learning difficulties in public speaking. Procedia - Social and Behavioral Sciences, 64, 671680. https://doi.org/10.1016/J.SBSPRO.2012.11.079

Miles, M. B., \& Huberman, A. M. (1994). Qualitative Data analysis; an expanded sourcebook. New Delhi: Sage Publication.

Moghavvemi, S., Sulaiman, A., Jaafar, N. I., \& Kasem, N. (2018). Social media as a complementary learning tool for teaching and learning: The case of youtube. The International Journal of Management Education, 16(1), 37-42. https://doi.org/10.1016/J.IJME.2017.12.001

Moreno, A. I., \& Vermeulen, A. (2015). Using VISP (videos for speaking), a mobile app based on audio description, to promote english language learning among spanish students: a case study. Procedia - Social and Behavioral Sciences, 178, 132-138. https://doi.org/10.1016/J.SBSPRO.2015.03.169

Park, H.-R., \& Kim, D. (2017). English language learners' strategies for reading online texts: Influential factors and patterns of use at home and in school. International Journal of Educational Research, 82, 63-74. https://doi.org/10.1016/J.IJER.2017.01.002

Riswandi, D. (2016). Use of youtube-based videos to improve students' speaking skill. In Proceeding The 2nd International Conference On Teacher Training and Education (Vol. 2, p. 269). J.C. Huber. Retrieved from https://jurnal.uns.ac.id/ictte/article/view/8150

Robinson, R. S. (2014). Purposive sampling. In Encyclopedia of Quality of Life and Well-Being Research (pp. 5243-5245). Dordrecht: Springer Netherlands. https://doi.org/10.1007/978-94007-0753-5_2337

Saeed, K. M., Khaksari, M., Eng, L. S., \& Ghani, A. M. A. (2016). The role of learner-learner interaction in the development of speaking skills. Theory and Practice in Language Studies, 6(2), 235. https://doi.org/10.17507/tpls.0602.03

Sayuri, S. (2016). Problems in speaking faced by efl students of mulawarman university. Indonesian Journal of EFL and Linguistics, 1(1), 47-61. https://doi.org/10.21462/ijefll.v1i1.4 